\title{
The Shattering Symmetries between the Imaginary and the Symbolic in Carter's The Magic Toyshop
}

\section{Nurten BIRLIK' ${ }^{1}$}

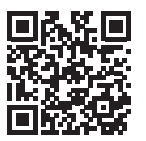

${ }^{1}$ Prof. Dr., Middle East Technical University, Faculty of Education, Department of Foreign Language Education, Ankara, Turkey

ORCID: N.B. 0000-0002-4544-9595

\section{Corresponding author:}

Nurten BiRLiK,

Middle East Technical University, Faculty of Education, Department of Foreign Language Education, Ankara, Turkey E-mail: nbirlik@metu.edu.tr

\section{Submitted: 12.12 .2020}

Revision Requested: 15.02.2021 Last Revision Received: 03.03.2021 Accepted: 06.04.2021

Citation: Birlik, N. (2021). The shattering symmetries between the imaginary and the symbolic in Carter's The Magic Toyshop. Litera, 31(1), 1-17.

https://doi.org/10.26650/LITERA2020-839744

\begin{abstract}
The Magic Toyshop tells the story of three siblings (Melanie, Jonathan and Victoria) and what they go through in Uncle Philip's house, where they find themselves in a totally different psychic space which is characterised by the resonances of the imaginary and in which images function differently. Among these images, animal imagery is central to Melanie's depiction of both the inhabitants of the house and the house itself. Through its emphasis on the images, along with the hard facts of life, the novel gives expression to the psychodynamics and the evolution (or lack of it) of the characters, and offers a context which attracts attention to the difference between the symbolic and the imaginary; also between the symbolic and the social, in Lacanian terms. Due to their foregrounded awareness of the imaginary dimension of material reality and Melanie's role in transposing Finn to a union in which the symbolic codes prevail, the ending of the novel implies that rather than the traditional hierarchy of the patriarchal discourse, there will be another kind of relationship between Finn and Melanie. This essay aims to bring up a new hermeneutical frame about the novel through the discussion of the significance of their move from the symbolic to the imaginary, how they relate to material reality through images in Philip's house, and how Melanie (with Finn) moves back to the symbolic, against the background of Lacanian ideas about the three registers, the logic of the signifiers, the imaginary father and 'object little a'.
\end{abstract}

Keywords: Angela Carter, The Magic Toyshop, Lacan, literature, psychoanalysis 


\section{Preamble}

Carter's The Magic Toyshop embodies two different psychic spaces, one is located in the symbolic, is given in the early pages of the novel and is characterised by intersubjectivity (which comes into being after the subject's entry into language) and the other is located in Uncle Philip's house, or as I claim, in the imaginary register, which is characterised by intrasubjectivity (which is the dimension of the identificatory processes before internalising the logic of the signifiers or linguistic castration). After the siblings arrive in London, Uncle Philip imprisons them in his house which becomes the whole universe to them. However, in this house rather than the logic of the signifiers, the logic of the images prevails and in the course of the events Melanie is exposed to an uncanny realm where images and signifiers are employed differently and where different identificatory relations (from the ones in the symbolic) dominate. It is because of this emphasis put on the imaginary register that the novel demands a Lacanian reading: Lacanian epistemology leads to a new hermeneutical reception of the novel due to its potential to account for the imaginary register. In this essay I seek to bring up a new psychoanalytical hermeneutical frame regarding the images and their implications in the novel consulting Lacanian ideas on the three registers, 'object little $a^{\prime}$, the logic of the signifiers, and the imaginary father as my conceptual backcloth. Among the images that invade Uncle Philip's house, animal imagery is the recurring element, therefore, for the sake of argumentative coherence, I will seek to explore how the characters relate to material reality in the imaginary register through the animal imagery in the novel.

Along with the hard facts of life, The Magic Toyshop gives expression to the psychodynamics and its evolution in characters, therefore, a chronological account of the narrative is significant to trace their evolution (or lack of it). Right in the beginning of the novel, we are told that the siblings' father is a famous writer and their parents are on a lecture tour in America. From the details about the house and the kind of life they lead, we infer that this is a well-to-do family whose living standards are fairly above the average. However, they receive a telegram informing them of a plane crash and their parents' death. After the death of their parents, from their previous position as the functioning members of the mainstream culture, these siblings move towards the margins in South London, to Uncle Philip's house, which accommodates Uncle Philip, his wife Margaret and her two brothers, Finn and Francie. Melanie likens their train journey to "a kind of purgatory, a waiting time, between the known and completed past 
and the unguessable future which had not yet begun" (Carter, 1996, p. 32). Later on, we realise that this train journey was also like a Dantesque antechamber to their forthcoming hellish life in South London, a kind of a fall from grace, a fall from the heavenly world of their f/Father to the hellish world of Uncle Philip/ the imaginary Father. They will fall from their social segment and through their fall, the narrative will offer us a re-writing of the biblical fall in both social and psychic terms. Later on in the novel, when Melanie looks back on her past, it seems tenuous and insubstantial to her. She likens their fall to that of Eve: "Eve must have felt like this on the way east out of Eden ...And it was Eve's fault" (Carter, 1996, p. 94). She likens their previous life to "a Pre-Raphaelite painting" which is gone but much missed (Carter, 1996, p. 53). This journey and its depiction as a fall lends itself for a Lacanian reading as this journey implies that Melanie (with Finn) will try to go back to the time before the fall and undo what this fall has cost her. In fact, the novel can be taken as fictionalisation of Melanie's disconnection from the symbolic, her fall into the imaginary register dominated by Uncle Phillip and return to the symbolic space. The essay keeps silent about the other siblings Victoria and Jonathan, due to lack of ample evidence as one is too young to speak and the other is not given voice and kept at the background of the events in the novel.

In Uncle Philip's big house, whose first floor serves as the toyshop, they also live and make toys. It is the whole world to them. They have only the basic of everything in their life, in both physical and emotional terms: "There was no television set, no record player, not even a radio" (Carter, 1996, p. 90). The question posed by Melanie is, how can she go back to her previous life and relations, which were part of the mainstream culture, in the future as long as she continues to live in this house, which is characterised by Uncle Philip's irrational oppression and the Jowles' incestuous transgressions? Her father's discourse (that is, the way he represented the symbolic at home and his capacity to be a metonymic extension of the paternal metaphor), which was located in the mainstream culture, was where Melanie located herself in the beginning but after encountering Uncle Philip's oppression and Finn's attraction to her, she finds herself in the unconventional discourse of the house, first as an observer then gradually as a participant. She is determined to "make herself at home somehow" despite all the poverty and lack of comfort in this house (Carter, 1996, p. 58). Still, she likens this house to Bluebeard's Castle due to the uncanny elements it embodies (Carter, 1996, p. 82).

Palmer aptly states that the novel is a reworking of three texts, "the biblical story of the Garden of Eden, E.T.A. Hoffmann's tale The Sandman and Freud's account of the 
psychic structures relating to the family unit..." $(1987$, p. 183). With their arrival in Uncle Philip's house, the siblings are exposed to the imaginary space which involves the resonances of the second and third texts in Palmer's statement in which characters' psychodynamics dominates the narrative. This essay takes Palmer's categorisation as its departure point and, as stated above, explores the novel taking the Lacanian theory as its conceptual backcloth and discusses that the siblings move from the world of their father who functioned as a metonymic extension of the Law to the world of Uncle Philip who is unable to position himself in the symbolic though he has a position in the social world. This essay also underlines that the novel offers a context which attracts attention to the difference between the symbolic and the social in Lacanian terms.

\section{The Mirror and the Apple Tree}

Among the three siblings, Melanie's vantage point is central to the narrative and the readers can penetrate into the novel mostly though her account of the things and the narrative time. A small scene in the beginning represents the schematic pattern of the whole novel in a nutshell as in this scene Melanie is located first in her father's house (which is dominated by the Law/ the Father's discourse and where the biological father can function as the metonymic extension of the paternal metaphor), then moves outside into open nature which we can take as regression to the pre-symbolic, and then comes back into the house after being traumatised. This schematic pattern will be fictionalised in the forthcoming pages of the novel through a wider lens. Although Melanie's fall is given through its Christian resonances, it also makes sense if we take it as a (metaphorical) regression and contributes to the argumentative texture of our interpretation.

In the early pages of the novel, Melanie, who is fifteen, is depicted as someone who is growing into sexual maturity and examines herself in the mirror by paying particular attention to her body, exploring it with a sensuously metaphorical language. In front of the mirror, she imagines herself in different forms as the object of desire and "sees herself through [her father's] eyes", there is also "a wonderfully self-absorbed autoeroticism" (Gamble, 1997, p. 69). The fact that she is undergoing sexual awakening is implied as follows: "After she read Lady Chatterley's Lover, she secretly picked forgetme-nots and stuck them in her pubic hair" (Carter, 1996, p. 2). This particular novel by D. H. Lawrence was censored in Britain for a long time for its 'obscene' scenes and the 'immoral' implications it bore about the heroine, who 'stooped' to infatuation with a man below her social status. Such implications about different forms of transgression 
prepare the ground for the forthcoming transgressions in Melanie's life, in both sensuous and social terms, as her later fall into the imaginary register of Uncle Philip's house implies transgression of the symbolic norms or the Law. The text underlines another detail about her: "She had a well-developed sense of guilt, that summer" (Carter, 1996, p. 5), a detail that hints at her changing position in the symbolic regarding her ego ideal identification. One night she could not sleep and "the red, swollen moon winked in the apple tree" (Carter, 1996, p. 9). Here the presence of the moon and the apple tree are significant in terms of her sensuous awakening as the moon is associated with woman, irrationality, the body, the dark side of life, instability, the repressed or the return of the repressed in dichotomous logic, and occupies the opposite leg of binarism against the sun, which is associated with man, rationality, mind, God, light, stability in the phallocentric discourse. Likewise, the apple tree is associated with carnal desire, which caused the good to fall from grace. She depicts the apple tree in a new light: "But this fruit, tonight, when she was so scared, seemed sinister poison apples, as if even her playmate tree had turned against her and there was no comfort in it" (Carter, 1996, p. 20).Despite the implicit awareness regarding the carnal desire, Melanie cannot venture too far from the discourse of the f/Father: "She kept as close to the house as she could,... the house was some protection. Her blood throbbed in her ears; the noise it made could have been the raucous breathing of the monsters around her" (Carter, 1996, p. 19). She manages to get into the house with difficulty, destroying her mother's dress. While she was climbing the tree, she:

hung in agony by her hands, strung up between earth and heaven, kicking blindly for a safe, solid thing in a world of all shifting leaves and shadows. Apples tumbled continually as she moved, and the waning moon blinked between leaves that thrust leathery hands spitefully into her eyes and into her gasping mouth. (Carter, 1996, pp. 21-22)

The situation of being "between earth and heaven," "in agony" looking for a secure ground in a world of "shifting leaves and shadows" (or flying signifiers in Lacanian terms) is one of the main themes in the novel. It might be taken as the intersection of the imaginary and the symbolic, as in this analogy the earth represents the empirical reality and heaven might be taken as the social reality/culture after the earth is incorporated into the symbolic. Climbing the tree (which has phallic significance) can be interpreted as an attempt to be positioned in the symbolic letting the master signifier organise her flying signifiers. 
Wyatt takes the opening pages of the novel as a "prolonged mirror stage," and Melanie "not as an agent but as an object of gaze" (2000, p. 71). Peach takes Melanie's scene in front of the mirror as a replay of the subject's relation with the imago (2009, p. 72). In a similar line of thinking, I take it as Melanie's disconnection from her parents' imaginary significance. Destroying their pictures and cracking the mirror, too, might be taken at both a literal and a metaphorical level. Her parents become dead to her with their imaginary implications. This is a very significant loss as, in a Lacanian frame of thinking, the subject constitutes himself/herself through identificatory confusion in reference to others, in a language specific context, and this fundamental misrecognition is the core of subjectivity. This identificatory confusion in the imaginary is constituted by imagos, which are unconscious images that determine how the subject apprehends other people in the symbolic register, as these imagos become the subject's structuring projections (Lacan, 2006, p. 2). This scene can be taken as an expression of Melanie's disconnection from her mother and what she represents in the imaginary psychic space of home. She will not feel relieved until she finds a new imago in Finn in her new life in Uncle Philip's house.

\section{Uncle Philip's House}

Uncle Philip is indifferent to their arrival and does not give them a warm welcome. In fact, he ignores Melanie in their first encounter, instead, beats Finn for being late for three minutes (Carter, 1996, p. 69). He is a big and frightening figure for Melanie: "Blocking the head of the stairway on the kitchen landing was the immense, overwhelming figure of a man" (Carter, 1996, p. 69). The following quotation from the text consolidates Melanie's earlier impressions:

Uncle Philip never talked to his wife except to bark brusque commands. He gave her a necklace that choked her. He beat her younger brother. He chilled the air through which he moved. His towering, blank-eyed presence at the head of the table drew the savour from the good food she cooked. He suppressed the idea of laughter. (Carter, 1996, p. 124)

Along with Uncle Philip there are three siblings in the house, Margaret, Fin and France. Margaret is married to Uncle Philip and her brothers help them in running the toyshop. Unlike Uncle Philip, Aunt Margaret welcomes them wholeheartedly. Victoria seems to become the longed for baby for her. She treats them with a "naked, maternal 
expression" which is, for Melanie, "both embarrassing and touching" (Carter, 1996, p. 48). Hers is maternal love untainted by the symbolic elements; moreover, she gives expression to it by non-linguistic means such as touch and look, which are extrasymbolic ways of achieving intrasubjectivity. The way she is depicted employs surrealistic elements:

Then she kissed Melanie... taking her in a stiff, Dutch-doll embrace; her arms were two hinged sticks, her mouth cool, dry and papery, her kiss inhibited, tight-lipped but somehow desperate, making an anguished plea for affection. She darted off straight after that, leaving Melanie fingering her cheek in surprise. (Carter, 1996, pp. 48-49)

These surrealistic elements underlined in Aunt Margaret's way of relating herself to them resonate the uncanny for Melanie, something which is repressed but deeply familiar to her. Her "plea for affection" and extra-non-symbolic ways of achieving intrasubjectivity with them contribute to Margaret's image as the slightly remembered motherly intimacy.

These people are in shabby clothes, dirty and smelly: "A ferocious, unwashed, animal reek came from them both; in addition, Finn stank of paint and turps on top of the poverty-stricken, slum smell. And Francie's collar, she saw, was rimmed with dirt and his neck was filthy" (Carter, 1996, p. 36). This detail about their bodily hygiene is the first indication of a fall for Melanie as it foreshadows their fall into the world of images, auditory or olfactory, from the world of language, and also of a fall into a lower social level as foreshadowed by the reference to Lady Chatterley's Lover. This reference to hygiene is a recurring element in the course of the novel. Using animal imagery while depicting these people is another recurring element. Due to the implications of these images and their potential as an alternative way of communication and relating to the material reality, the journey of the siblings seems to be one from the humanised to the pre-humanised (or from acculturation, the logic of the signifiers to pre-acculturation, the pre-linguistic) in Lacanian terms. Aunt Margaret is likened to birds: "Aunt Margaret was bird like herself, in her hither-and-thither movements and a certain gesture she had of nodding her head like a sparrow picking up crumbs. A black bird with a red crest and no song to sing" (Carter, 1996, p. 42). Finn is likened to a satyr by Melanie (Carter, 1996, p. 54). Elsewhere he is likened to a goat: 
Finn padded with a squishy noise on his bare and filthy feet. And, his toenails were long and curved, like the horns of a goat, reminding Melanie of the cloven hooves she thought he might have had. His toe-nails looked as if a knife would blunt on them and could not have been cut for months, possibly years. (Carter, 1996, p. 64)

In the park, Finn "was grinning like Pan in a wood" (Carter, 1996, p. 105). All these words, satyr, goat and Pan (which are reminiscent of the pre-Christian times) have similar connotations; carnal desire or flowing passions. Their marginal status is emphasised each time they are referred to as "the red people." The colour red being the colour of passion adds up to the other implications attached to them. Through these implications, they are affiliated with the repressed of the communal culture, or the flowing and unregulated passions of pre-acculturation.

Likewise, the shop is full of anthropomorphic toys (Carter, 1996, p. 92). The fact that these puppets are mostly inspired by mythological legends and figures enriches their connotations and metaphorical implications. Very suitably, the most valuable set for Uncle Philip was Noah's Ark, which was a masterpiece according to Melanie. The characters on it are modelled after the household members. In such a context, it comes as no surprise that the boat is one of the important metaphors in the novel. It symbolises many things at once: their isolation, their closeness to the origins of human life, the margins of the symbolic, limbo situation etc. We can even say that it symbolises Uncle Philip's house and the household. In such a context, we are not amazed when Melanie likens Uncle Philip to the Beast of the Apocalypse. In such a context, "humans, animals and toys inhabit the same dimension in this text"(Sage, 2007, p. 15). This "same dimension" where animals assume psychic implications or are used to objectify psychic dynamics of the people living in the house implies blurring of the boundaries between the human and the pre-human, castration and pre-castration, acculturation and pre-acculturation. This merging is at the same time fictionalisation of the Lacanian imaginary register that involves the intrasubjectivity in the house.

Interestingly enough, the animal image that is associated with Melanie is picked from Christian times, the $\mathrm{f} /$ Father's culture, not from the pagan background unlike the depiction of the other characters. She sleeps with Edward Bear, which is one of the few things Melanie brings to London. She cannot do without it as she"had lived with Edward Bear for ten years" (Carter, 1996, p. 44). This bear, another magic toy and a symbol of 
masculine energy, giving her a sense of safety to hold on to life, can be taken as an upholstery button/ point de capiton through which "the signifier stops the otherwise endless movement of the signification" (Lacan, 2006, p. 303). They are points at which 'signified and signifier are knotted together' (Lacan, 1993, p. 268). The subject should have a certain amount of upholstery buttons: 'when they are not established, or when they give way' the result is PSYCHOSIS (Lacan, 1993, pp. 268-9). Edward Bear is Melanie's upholstery button to achieve her psychic coherence, that is, it is through Edward Bear that Melanie manages to stabilise the fragments in her life. However, the fact that this toy bears cultural resonances related to the paternal metaphor makes her toy different from the others (mostly from the pre-Christian times) that are made in Uncle Philip's house. In other words, while Uncle Philip's toys bear imaginary resonances Melanie's toy bears symbolic resonances.

\section{Uncle Philip as the Imaginary Father}

Uncle Philip's house is located on a busy street in South London but, at the same time, it is cut off from the outside world as the members of this large household establish contact with the outside world only in matters of trade. Interestingly enough, the customers have to tolerate Uncle Philip's whims as he does not care much about the financial gain from his puppets. He is "his own master" and he "doesn't want people he despises buying his gear for conversation pieces" (Carter, 1996, p. 95). Philip does not give household members any money and does not take checks as "they're unnatural" (Carter, 1996, p. 137).

The first warning Melanie gets about Uncle Philip's ways is, he does not allow women in trousers to come into his premises, even to his shop. Finn warns Melanie on her first day when she is in her trousers (Carter, 1996, p. 62). This tells us something about his oppressive attitude if we look at the traditional connotations of trousers: masculine energy, maleness and power. When he sees a pair of trousers on a woman, his reaction implies resistance to the combination of femininity and masculine energy, and he takes this combination (which is a familiar but unacceptable behavioural pattern to him) as a challenge to himself. Another detail about Uncle Philip is, he is not in good terms with words: It is stated in the text: “Uncle Philip loved silence” (Carter, 1996, p. 90).

Uncle Philip terrorises them and does not hesitate to beat Finn harshly if he thinks necessary. He is a bully, who does not let them acknowledge other authority figures 
but who cannot command respect from others for his authority. He is like the Lacanian imaginary father who threatens to castrate his children by creating an extreme form of anxiety in them, yet doesn't promise any relief in any social positioning and who forbids any kind of social contact with significant others. For Lacan, intersubjectivity undercuts the traditional distinction between the inner and the outer, the subject and the symbolic as he emphasises that the subject holds a transferential relationship to significant others and the symbolic s/he is born into. Uncle Philip seeks to annihilate this intersubjective space to be achieved outside his house and he wants to be the absolute authority in their world but, in this process, he traumatises them. In order to cope with the sense of Lack caused by the symbolic castration, the subject needs to identify with the operative master signifier or the signifiers revolving around it, and believe itself to be self-identical (1991, pp. 177-178). This identification and gratification gives the subject a sense of unity and recognition which is essential for an awareness of an ego ideal.This is to say, the subject can position itself in culture due to this correlation between himself/herself and the organising elements in the symbolic (2006, pp. 95-97, pp. 229-231). However, the household members are trapped in a universe of castration anxiety, which annuls the narcissistic gratification to be achieved with ideal ego or ego ideal identifications and other forms of gratification, which ensue in the aftermath of the Oedipal resolution. Therefore, the household members are like the children who are doomed to live in castration anxiety forever being unable to benefit from other compensating mechanisms like symbolic gratification. This is a hellish situation, in Lacanian terms, where any form of relief/gratification is denied to them, or a Limbo situation in psychic terms where the subject is stuck somewhere at the intersection of the imaginary and the symbolic, and where none of them can function properly. In this oppressive world of Uncle Philip's, they are expected to make and sell toys, artefacts of imagination. Interestingly enough, Victoria, who can barely speak, is not allowed to play with any one of these toys. That is, even Victoria is not allowed to enjoy gratification. Due to all these details, we fall under the illusion that Uncle Philip enjoys endless narcissistic omnipotence but cripples (or he thinks that he can cripple) the ego identifications of the others. However, the following pages reveal that this is an illusion.

Among the Irish siblings, Finn can dance and paint very well. He paints Uncle Philip's puppets, toys and scenery. He is both frightened of and admires Uncle Philip: "He is a master' said Finn. 'There is no one like him, for art or craft. He's a genius in his own way and he knows it" (Carter, 1996, p. 64). Uncle Philip is an idol for him: "You see, the puppet theatre is his heart's darling, in a manner of speaking. Or obsession, rather. You should 
see the scenes he puts on! And sometimes he lets me pull the strings. That's a great day for me.' His voice curled ironically at the edges" (Carter, 1996, pp. 67-68). Due to these remarks, we can understand Linden Peach when he says that in some sections of the novel the line between Finn and Uncle Philip blurs (2009, p. 70). Armitt too suggests that Uncle Philip's authority rather than being eliminated is perpetuated by Finn (2000, p. 200). He seems to be a metonymic extension of or the ideal son for Uncle Philip in the earlier pages of the novel but this affiliation changes after he is attracted to Melanie, and Uncle Philip transfers his attention to Jonathon. Finn moves from an identificatory process with Uncle Philip to another psychic space where he gradually falls in love with Melanie.

As in the portrayal of the other characters, Uncle Philip too is given through animal imagery. In his Christmas puppet show, he directs the play "Leda and the Swan" whose script is written by himself. Leda and the Swan are acted in the play by Melanie and Finn, respectively.

Within a psychoanalytical frame of thinking, due to his absolute oppression and keeping gratification of all forms within his monopoly, I argue that Philip objectifies the Freudian Primordial Father in him in his puppet shows. Freud talks about the Primordial Father in Moses and Monotheism and Totem and Taboo*. This Primordial Father (whom sometimes Lacan refers to as obscene Father enjoyment) enjoyed limitless freedom and the members of the horde obeyed his dictates either out of habit or fear. As Freud says:

The strong male was the master and father of the whole horde, unlimited in his power, which heused brutally. All females were his property, the wives and daughters in his own horde as well as perhapsal so those stolen from other hordes. The fate of the sons was a hard one; if they excited the father's jealousy they were killed or castrated or driven out. (1939, p. 102)

The sons killed the father but after the killing they were over whelmed by guilt and established the totemic system. This is also the transition from the father to the Father in human culture: before the Name of the Father in fact, "there was no father, there

* What Lacan says about the Primordial Father might be of interest at this point of the argument: "[t]he important feature of Totem and Taboois that it is a myth, and, as has been said, perhaps the only myth the the modern age was capable of. And Freud created it" (1992, p. 176). 
were all sorts of other things. If Freud wrote Totem and Taboo, it was because he thought he could glimpse what there was, but before the term father was institute dinacer tain register historically there was certainly no father" (Lacan, 1993, p. 306). Like the Primordial Father, Uncle Philip is the omnipotent power in this process, the director, playwright, creator of the puppets, writer of the instructions to be followed by Finn and Melanie. He wants them to rehearse the play somewhere private, Finn realises that Uncle Philip prepares a context in which he will rape Melanie but he does not fall into Uncle Philip's trap. This intrigue by Uncle Philip suggests that this play has psychodynamic resonances for him. The fact that Melanie is his sister's daughter implies that he is acting out his incestuous impulses through Finn (his metonymic extension) on his sister through Meanie (his sister's metonymic extension). Then, the swan is a part object/'object little $a^{\prime}$ for Uncle Philip to regain the lost precious object, to evade language, to get back to the real. This can be explained in a Lacanian context as follows:

To enter language is to be severed from what Lacan calls the 'real', that inaccessible realm which is always beyond the reach of signification, always outside the symbolic order. In particular, we are severed from the mother's body: after the Oedipus crisis, we will never again be able to attain this precious object even though we will spend all our lives hunting for it. We have to make do instead with a substitute object, what Lacan calls the 'object little a', with which we try vainly to plug the gap at the very centre of our being. (Eagleton, 1983, pp. 145-6)

Jean Wyatt takes this play as a re-enactment of the Oedipal stage: The play "fulfils the function of the oedipal stage" that is, it "organises Melanie's sexuality to accord with her gender role" (2000, p. 65). Wyatt looks at the interaction between Philip and Melanie within the frame of father-daughter relations as it dramatises the "daughter's oedipal crisis in a way that heightens the power dimensions of father-daughter relations." She argues that in the novel Carter reveals female acculturation into patriarchy in which "woman's subjectivity is erased as she is inserted into the patriarchal order. As the exaggerated conventionality of his patriarchal traits suggests, Philip's puppet workshop represents more than a family business: it doubles as a cultural site where the myths that sustain patriarchy are fabricated" (2000, p. 67). Wyatt takes Philip as the extension of the linguistically castrating Father. In a similar line of thinking, Gamble (1997, p. 71) says that, "Uncle Philip is patriarchy incarnate, less a character than barely embodied principle." Peach looks at the interaction between Melanie and Uncle Philip within the 
Kleinian frame of object relations and takes Uncle Philip as the negative imago (2009, p. 71). However, like other critics, she takes Uncle Philip as the intrusion of patriarchy. Likewise, Jouve says that "[t]he trope is a patriarchal power trip" (2007, p. 169). Day says, "Uncle Philip is almost a caricature of the patriarch" turning others into puppets and "[t]he figurative message is that patriarchal power in the world turns people into puppets, deprives them of autonomous life" (1998, pp. 23-24). Sage takes Philip as "a parody-patriarch" (2007, p. 15) and Müller takes him as "the archetypal paterfamilias" (1995, p. 14). Palmer states that, Carter "makes the puppet-master as symbolic of the control exerted by a patriarchal culture on women and the roles available to them" $(1987$, p. 183). All these interpretations make sense if Uncle Philip is taken as a member of the symbolic. However, a Lacanian vantage point offers another layer of hermeneutics as it distinguishes between the symbolic and the social. Within a Lacanian frame of thinking we cannot locate Uncle Philip in the symbolic because being in the symbolic takes as its founding principle the acknowledgement of the incest taboo. These characters are in the social in London, doing business with others but not in the symbolic which "is precisely what sets limits to any and all utopian efforts to reconfigure and relive kinship relations at some distance from the Oedipal scene" (Butler, 2000, p. 20). In the symbolic the paternal metaphor forestalls the subject's incestuous desires and the subject renounces the incestuous desire and submits to the paternal metaphor: "The Law of the father is thus the threshold between nature and culture according to which the individual is prohibited from having sexual relations with those 'named' as 'kin"' (Lloyd, 2007, p. 89). One can be a functioning link in the social chain but it does not guarantee that $\mathrm{s} / \mathrm{he}$ is in the symbolic. At this point it might be helpful to look at what Butler says about the distinction between the symbolic and the social in Lacan when she discusses the conflict between Antigone's act and norms:

As symbolic, these norms are not precisely social, and in this way Lacan departs from Hegel, we might say, by making a certain idealized notion of kinship into a presupposition of cultural intelligibility. At the same time Lacan continues a certain Hegelian legacy by separating that idealized sphere of kinship, the symbolic, from the sphere of the social. (2000, p. 3)

The incest taboo is the universal Law in the symbolic but it is not acknowledged by Uncle Philip, who is unable to submit to the Law. Uncle Philip's inability to castrate the siblings (to disconnect them from the imaginary register and the motherly space) despite his terrorising attitude deserves attention. We can say that in the play "Leda 
and the Swan" as he acts out a dramatic version of this incestuous transgression, he establishes the imaginary fusion with the other, in the symbolic. That is, he recreates the imaginary identificatory processes in the symbolic. However, he is a businessman in a patriarchal social space too. It is due to this discrepancy that the novel works as a complimentary afterthought to the previous feminist readings. Uncle Philip is far from representing the patriarch, just the opposite, like the Freudian Primordial Father he is the one who himself cannot submit himself to the Law. Then there is no way for him to be in the symbolic. Another point that supports this argument is the above mentioned image of him as the imaginary father who keeps the infant in castration anxiety but who is unable to disconnect him/her from the motherly space by leading him/her to linguistic castration and symbolic identificatory processes. The later pages of the novel reveal that there is another case of incestuous intercourse going on between Margaret and Francie. Finn is a witness to this and has no objection. In this imaginary register, they engage in a Dionysian ritualistic process by both making music and dancing and, very suitably, they are likened to goats, which imply carnal desire. When Finn falls in love with Melanie, he proves willing to disconnect himself from the imaginary register of this incestuous intercourse and relate to the coordinates of the symbolic. Then it is not Uncle Philip but Melanie who castrates Finn. In other words, by leading Finn to heteronormativity to be achieved in the symbolic Melanie transposes him from one space of psychodynamics to another space that is located in the symbolic.

\section{The Ending of the Novel as an Act and Geometry of Equality}

After seeing Melanie being "raped" by the swan, Finn paints a picture, which becomes an objectification of his unconscious material. In the painting:

Uncle Philip was laid out on a charcoal grill like a barbecued pork chop. He was naked, gross and abhorrent.... His white hair was budding in tiny flames. Beside him stood a devil in red tights with horns and a forked tail. He held a pair of red hot tongs in his hands with which he was tweaking Uncle Philip's testicles.... His mouth was a black, screaming hole from which issued a banner with the words: 'Forgive me!' the devil had Finn's former, grinning face. (Carter, 1996, p. 154)

Finn's act reminds us of the Freudian Primordial Father again. Only when he is killed by his sons, he is acknowledged as in the case of the Father. In Finn's case, only after 
Finn destroys the swan, the metonymic extension of Uncle Philip, can Finn liberate himself from Uncle Philip's image as the Primordial Father. Finn's act can be taken as an attempt at meaning and the logic of the signifiers or language in Lacanian terms. In language,

The subject attaches significance, it 'anchors itself' to certain signifiers; these signifiers, like upholstery buttons, pin down the floating mass of signification, by attaching it to the system of signifiers. If they fail, the correspondence is no longer achieved, words no longer carry meaning and communication, or inter-subjectivity fails. (Sarup, 1992, p. 108)

This level of reading impels us to reread the ending of the novel in which Uncle Philip sets the house on fire after he discovers the incestuous intercourse between Margaret and Francie, returning unexpectedly from a business trip. Only Melanie and Finn manage to escape the fire which they watch from afar. It is interesting that the novel does not end on a pessimistic note. This lack of a sense of catastrophe in the ending implies that the death of the other characters might also be taken on a metaphorical level. Finn and Melanie are now positioned in the symbolic register leaving the imaginary hell of Uncle Philip behind.

With such an ending, Armitt says that Melanie runs "from the arms of one father figure into the arms of another" and "[a]ll evidence points towards Melanie's life with Finn following the same patterns as the other transactions. Finn and Philip do not just share a phonetic similarity of names, they also share a fascination with women as spectacular commodity" (2000, p. 206). Likewise, Palmer takes the ending of the novel as "a symptom of the continuing power of patriarchy"(1987, p. 187). However, these critics seem to disregard the point that Melanie is more empowered in this symptom. It is Melanie who is familiar with this new space in which she will be guiding Finn on an equal footing. In fact, Melanie can be more than equal in this relationship, being there in the symbolic earlier, she has the potential to play the upper hand. That is, rather than the traditional hierarchy, there will be another kind of relationship between them. We might take this as Carter's response on a feminist ground. In this relationship Melanie will assert her agency without being oppressed by Finn. This is an alternative that goes beyond the dichotomous logic of patriarchy. It also implies transformation through transgression (of the model offered by the patriarchal discourse). 
In this ending, as Wyatt states, Melanie reveals "a geometry of equality" (2000, p. 35). By lifting Finn up, she acquires agency. This is an Act, in Žižek's sense, which "accomplishes what, within the given symbolic universe, appears to be'impossible,'yet it changes the conditions so that it creates retroactively the conditions of its own possibility" (2000, p. 121). An Act "disturbs the symbolic field into which it intervenes not out of nowhere but precisely from the standpoint of this inherent possibility..." (2000, p. 125). That is, Melanie shatters the normative patterns of the patriarchal discourse not from the imaginary by denying the Law (like Uncle Philip, Margaret and Francie) but from within the symbolic by creating a new space of intersubjectivity within the space of the Law.

This kind of an ending bears within itself the risk of being taken as a typical Freudian closure. However, if we look at the narrative implications closely, we should take it as one of the scenes where we hear Lacan most. In his epistemology, Lacan gives the priority to the subject's submission of itself to the logic of the signifiers/ the Law/ the paternal metaphor, which he calls the linguistic castration. For him this is the nodal point of entry into the symbolic, therefore, he also calls this the humanising moment. In this line of argument, when Melanie prefers to locate herself in a symbiosis with Finn and disconnects herself from the imaginary register of Uncle Philip's house that denies the taboo of incest but objectifies different forms of it, she actualises what Lacan calls intersubjectivity, that is, she allows for the intrusion of the third element, language, in her relation to the material reality. Interestingly enough, as stated above, Melanie will be the guide for Finn in this journey as she had already been there earlier.We can even go so far to say that the ending acts out a fictionalised version of linguistic castration for Finn with a shifting of perspective as it is Melanie who lifts him up from the imaginary to the symbolic. This is another way of saying that Melanie will function as the metonymic extension of the paternal metaphor, not Finn. This is a far cry from a possible Freudian closure to the novel. In this ending, the question of whether they will be able to exist in the social or not is left unanswered. This might be the reason why, in the aftermath of the ending, the readers go on speculating about the forthcoming phases of their journey. 
Peer-review: Externally peer-reviewed.

Conflict of Interest: The author has no conflict of interest to declare.

Grant Support: The author declared that this study has received no financial support.

Hakem Değerlendirmesi: Dış bağımsız.

Çıkar Çatışması: Yazar çıkar çatışması bildirmemiştir.

Finansal Destek: Yazar bu çalışma için finansal destek almadığını beyan etmiştir.

\section{References}

Armitt, L. (2000). Contemporary Women's Fiction and the Fantastic. Basingstoke: Macmillan.

Butler, J. (2000). Antigone's Claim. New York: Columbia UP.

Carter, A. (1996). The Magic Toyshop. New York: Penguin.

Day, A. (1998). Angela Carter: The Rational Glass. Manchester, UK: Manchester UP.

Eagleton, T. (1983). Literary Theory. Oxford: Blackwell.

Freud, S. (1939). Moses and Monotheism. (K. Jones, Trans.). New York: Vintage.

Gamble, S. (1997). Angela Carter: Writing from the Frontline. Edinburgh: Edinburgh UP.

Jouve, N. W. (2007). Mother is a Figure of Speech... In L. Sage (Ed.), Essays on the Art of Angela Carter Flesh and the Mirror (pp.151-183). London: Virago.

Lacan, J. (2006). Écrits, The First Complete Edition in English. (B. Fink, Trans.). New York: W.W. Norton.

---.(1991). Le Séminaire, Livre XVII: L'envers de la psychanalyse (text established by J.A. Miller). Paris: Seuil.

---. (1993). The Psychoses: The Seminar of Jacques Lacan Book III.In J. A. Miller (Ed.). (R. Grigg, Trans.). London: Routledge.

---. J.(1992). The Seminar of Jacques Lacan Book VII The Ethics of Psychoanalysis 1959-1960. In J.A. Miller (Ed.), (D.

Porter, Trans.). New York: W.W. Norton.

Lloyd, M. (2007). Judith Butler: From Norms to Politics. Cambridge: Polity P.

Müller, A. (1995). Angela Carter Identity Constructed / Deconstructed. Heidelberg: Universitätverlag C. Winter.

Palmer, P. (1987). From 'Coded Mannequin' to Bird Woman: Angela Carter's Magic Flight. In S. Roe (Ed.), Women Reading Women's Writing (pp.179-205). Brighton: Harvester P.

Peach, L. (2009). Angela Carter. (2 ${ }^{\text {nd }}$ ed.) Houndmills, Basingstoke, Hampshire and New York: Palgrave Macmillan. Sage, L. (2007). Introduction. In L. Sage (Ed.), Essays on the Art of Angela Carter (pp.20-42). London: Virago.

Sarup, M. (1992). Jacques Lacan. New York: Harvester Wheatsheaf.

Wyatt, J. (2000). The Violence of Gendering: Cartesian Images in Angela Carter's The Magic Toyshop, The Passion of New Eve, and 'Peter and the Wolf'. In A. Easton (Ed.), Angela Carter (pp.58-83). Houndmills, Basingstoke, Hampshire: Palgrave Macmillan.

Žižek, S. (2000). Class Struggle or Postmodernism? In E. Laclau, J. Butler and S. Žižek (Eds.), Contingency, Hegemony, Universality: Contemporary Dialogues on the Left(pp.90-11). London and New York: Verso. 
